\title{
麹菌リパーゼ高生産株の育種とみその試 験醸造
}

醸造用麹菌は, 種瞵メーカーによって多くの品種が開発されている。みそ醸造用種麹もそれぞれの用途に 適した品種が市販されているが, 酒造用との品種に比べてそれほどバラエティーが多くないのが現状である。 みそ醸造にも麴菌が主要な役割を果たしており, 近年みそ醸造用に着目した麹菌品種の開発が行われるよう になってきた。著者は, 麹菌のリパーゼについて分子生物的な研究を実施され, リパーゼ生産性の高い品種 の開発に取り組んでこられた。そこで, 帾菌の高リパーゼ生産性菌株の育種ならびにみそ醸造におけるリパ 一ゼの作用とその重要性について解説していただいた。

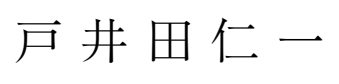

\section{1. はじめに}

みその生産量は微減傾向が続いているが, それに対 し業界の「みそ健康づくり委員会」ではみその機能性 に着目し，効能，健康イメージを PRすることにより， 消費の拡大を図っている。みその様々な機能性, 効能 については海老根 ${ }^{1)}$ や渡邊 ${ }^{2)}$ の総説などでまとめられ ており, 機能性成分の同定, 機能性成分の作用機構の 解明, 新たな機能性やその成分の探索といった基礎的 な知見が蓄積されつつある。同時に基礎研究のみなら ず, こうした流れに合致し, 健康志向に沿って機能性 を強化した製品開発が求められている。その場合, 食 品であるからには当然のことながら官能的にも優れて いる必要がある。

著者らは, 数あるみその機能性成分の中で, 香味成 分でもある脂肪酸や脂肪酸エチルに着目している。脂 肪酸や脂肪酸エチルに関しては, 山本らは脂肪酸 ${ }^{3)}$, 岡崎らは脂肪酸エチル ${ }^{4)}$ を抗変異原性成分として報告 している。また, 上岡らは脂肪酸エチルをガン細胞増 殖抑制成分であると報告している ${ }^{5)}$ 。一方, 安平らは, 脂肪酸エチル量がみその官能評価結果と相関があり,

香りの基礎となっていると報告しており ${ }^{6)}$, 官能的に も重要な成分であると考えられる。

みその脂肪酸や脂肪酸エチルは, 発酵・熟成に伴う
脂質変化によって生じる成分である ${ }^{7)}$ 。大西らの報告 のように脂肪酸エチルの生成には，リパーゼの作用 ${ }^{8)}$, エステル化のためのエタノール ${ }^{99}$ が必要であり, 発酵 過程を経ない生鮮食品や加工食品にはほとんど含まれ ていないと考えられる。また, 清酒や槒油といった他 の発酵食品には脂質自体ほとんどあるいは全く含まれ ていない。このように，脂肪酸や特に脂肪酸エチルは， みそ以外の食品には含有量が非常に少ないと考えられ, みそに特徵的な成分として興味深い。

著者らは, みそ熟成中の脂質変化を担う麹菌リパー ゼに関して基礎的な研究を行ってきた。酵素の精製及 び諸性質を調べることにより, 基質特異性等が異なる 3 種類の脂質分解酵素が存在することを明らかにした 10,11)。更にそれらの遺伝子のクローニング・シークエ ンス, 微生物による酵素の発現などを行った ${ }^{12)}$ 。

一方, 機能性を強化したみその開発という点では, 渡辺らが種趜メーカー所有の保存株よりみその抗変異 原性に基づく鰲菌を選抜しており，その趜菌はリパー ゼ活性が高く，それを利用したみそは脂肪酸含量が高 く, 抗変異原性が向上したみそになることを報告して いる ${ }^{13)}$ 。

本稿では, 香味が優れ, 機能性を高めたみそを開発 することを目的とし, 変異処理によってリパーゼ生産 性を高めた錮菌を育種するとともに，それをみそへ利

Breeding of High Lipase Producing Strain from Aspergillus oryzae and its Usefulness for Miso Fermentation Jinichi Toida (Nagano Prefecture General Industrial Technology Center) 
用して試験醉造を行ったところ，官能的にも良好で， ガン細胞増殖抑制能が向上したみそとなった事例 ${ }^{14)}$ を紹介したい。

\section{2. 変異処理による麹菌リパーゼ高生産株の育種}

高活性で多様性に富んだ麹菌リパーゼ高生産株の取 得を目指して, 変異処理による育種を行った。変異株 の親株として長野県工業技術総合センター保存株であ る Aspergillus oryzae KJ44を使用した。この胞子に 対し, N-methyl-N' -nitro-N-nitrosoguanidine (MNNG) により変異処理した。

リパーゼ高生産株は, $0.1 \% \mathrm{NaNO}_{3}, \quad 0.1 \% \mathrm{KH}_{2} \mathrm{PO}_{4}$, $0.05 \% \mathrm{MgSO}_{4} \cdot 7 \mathrm{H}_{2} \mathrm{O}, 2 \%$ ポリペプトン， $0.5 \%$ 酵母エ キス， $0.5 \%$ オリーブ油， $1 \%$ ラウリン酸ビニル， $1 \%$ 胆 汁末から成る選択用寒天培地により $30^{\circ} \mathrm{C} ， 3$ 日程度培 養した後, コロニー周辺のハローが大きな株を 1 次ス クリーニングした。さらに，それらについて米 $100 \mathrm{~g}$ 程度を使用して小型シャーレ内で製麦甸試験を実施し, 活性測定により 2 次スクリーニングした。敖のリパー ゼ活性は，オリーブ油を基質とするアルカリ滴定法に より測定した ${ }^{10)}$ 。その結果，親株である KJ44の活性 は $0.13 \mathrm{U} / \mathrm{g}$ ，市販種麹であるヒグチモヤシ BF-1 は $0.12 \mathrm{U} / \mathrm{g}$ であるのに対し， $0.41 \mathrm{U} / \mathrm{g}$ と 3 倍程度に高生 産するNT12 株を選抜した。

\section{3. 製麹試験及びみその小仕込試験}

麹菌リパーゼ高生産株の NT12 株を玄米に生育さ せ，胞子形成後ふるいにふるって胞子を集め，種䣱と した。米を常法に従って処理し，小型自動製表装置を 用いて $37^{\circ} \mathrm{C} ， 42$ 時間製趜した。製敖試験，仕込試験 は実用的な観点から実用株と比較するため，味増製造 に広く使用され，先のシャーレ試験において KJ44 株 と同程度のリパーゼ活性を有していたヒグチモヤシ BF-1 を対照株として用いた。NT12 株は対照株であ る BF 菌より製麦匊工程中全般的に生育が緩慢であり, 靝の締まりは弱く，破精まわりもやや劣っていた。第 1 表に䞤の酵素活性測定結果を示した。靝の分析は基 準みそ分析法等 ${ }^{10,15,16)}$ に従った。NT12 株はBF 菌に 比べ，鳌の $\mathrm{pH}$ が低く，生育が緩慢なためか水分は高 めであった。リパーゼ活性はシャーレでの製麹試験と 同程度の約 3 倍, プロテアーゼは若干低めであり, キ シラナーゼは約 2 倍であった。

小仕込試験は，第 2 表の配合（鍻歩合 10 割，予定 水分 $48 \%$ ，予定塩分 $12 \%$ ）によりみそを仕込み， $30^{\circ} \mathrm{C}$, 60 日間熟成させた。熟成 60 日におけるみその成分分 析結果及び官能評価結果を示した（第 3 表，第 4 表)。 みその成分は，基準みそ分析法 ${ }^{15)} に よ り$ 分析した。

全般的に試験区と対照区の成分值は，それほど大き な差異はなかった。色について Y 值はほぼ同じだっ

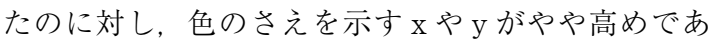

第 1 表 銤の酵素活性

\begin{tabular}{cccccc}
\hline & $\mathrm{pH}$ & $\begin{array}{c}\text { 水分 } \\
(\%)\end{array}$ & $\begin{array}{c}\text { リパーゼ } \\
(\mathrm{U} / \mathrm{g})\end{array}$ & $\begin{array}{c}\text { プロテアーゼ } \\
(\mathrm{pH} 6.0)\end{array}$ & $\begin{array}{c}\text { キシラナーゼ } \\
(\mathrm{U} / \mathrm{g})\end{array}$ \\
\hline $\mathrm{BF}$ & 5.70 & 24.3 & 0.13 & 62 & 0.16 \\
$\mathrm{NT} 12$ & 5.42 & 26.0 & 0.40 & 50 & 0.38 \\
\hline
\end{tabular}

第 2 表 みその仕込配合

\begin{tabular}{cc}
\hline 蒸煮大豆 & $5.2 \mathrm{~kg}$ \\
米麹 & $2.86 \mathrm{~kg}$ \\
並塩 & $1.24 \mathrm{~kg}$ \\
種水 (酵母含む) & $1.07 \mathrm{~L}$ \\
\hline 合計 & $10.4 \mathrm{~kg}$ \\
\hline
\end{tabular}

第 3 表 みその成分分析值 (熟成 60 日)

\begin{tabular}{|c|c|c|c|c|c|c|c|c|c|c|}
\hline & $\mathrm{pH}$ & $\begin{array}{l}\text { 水分 } \\
(\%)\end{array}$ & $\begin{array}{l}\text { 食塩 } \\
(\%)\end{array}$ & $\begin{array}{c}\mathrm{Y} \\
(\%)\end{array}$ & $\mathrm{x}$ & $\mathrm{y}$ & $\begin{array}{c}\text { アルコール } \\
(\%)\end{array}$ & $\begin{array}{l}\text { TN } \\
(\%)\end{array}$ & $\begin{array}{l}\text { FN } \\
(\%)\end{array}$ & $\begin{array}{l}\text { WSN } \\
(\%)\end{array}$ \\
\hline $\mathrm{BF}$ & 5.22 & 47.1 & 13.4 & 26.2 & 0.461 & 0.426 & 1.99 & 1.79 & 0.38 & 1.24 \\
\hline NT12 & 5.24 & 46.0 & 13.1 & 26.3 & 0.467 & 0.429 & 2.04 & 1.76 & 0.35 & 1.14 \\
\hline
\end{tabular}

第 4 表 みその官能評価 (5 点法, 対照区を 3 点とした相対評価)

\begin{tabular}{cccccc}
\hline & 色 & 香り & 味 & 組成 & 総合 \\
\hline BF & 3.0 & 3.0 & 3.0 & 3.0 & 3.0 \\
NT12 & 2.2 & 2.2 & 2.3 & 2.7 & 2.3 \\
\hline
\end{tabular}


り，ホルモール窒素（FN）や水溶性窒素（WSN）の 值が低めであった。窒素関連成分が低いのは，プロテ アーゼがやや低い影響であると考えられる。

官能評価では試験区は総合的にやや良い評価を得た。 色は成分值通りさえがやや強く，香りはやや特徵が感 じられたものの良好であった。味は旨味不足のような 窒素関連成分が低い影響は特には感じられず, 組成と ともに対照区とそれほど变わらない印象であった。色 のさえが強いのはキシラナーゼなどのへミセルラーゼ の活性が高い影響であることが考えられる。

続いて熟成 60 日のみそより脂質をエーテル抽出し ガスクロマトグラフィーにより脂肪酸及び脂肪酸エチ ル含量を定量した（第 1 図）。試験区のみそに含まれ る全脂肪酸量は対照区よりやや低かったものの, 全脂 肪酸エチル量は 1.1 倍程度に増加していた。また, 試 験区は脂肪酸と脂肪酸エチルの合計量も若干増加して いた。しかし、リパーゼ活性が 3 倍程度であることに 比べると脂肪酸エチルなどの増加率は低い結果にとど まり，期待したほどの効果ではなかった。その原因は いくつか考えられるが, これはNT12 株がどのような 種類のリパーゼを高生産しているのかと関連があると 考えている。先に述べたように著者らは基質特異性が 異なる 3 種類の趎菌の脂質分解酵素を確認している他 に，石田らによる別のリパーゼに関する特許出願があ $り^{17)}$, 麹菌ゲノム解析の結果でも存在が予測されて いるなど，多数のリパーゼが存在すると考えられる。 今回の試験後の継続的な試験により, NT12 株の贅の 酵素活性についてトリオレインに対してあまり作用し ていないデータが得られており，例えばこのNT12
はモノ及びジグリセリドリパーゼのようなリパーゼが 主として高生産されている可能性がある。

一般的にみその脂質は熟成に伴い，リパーゼの作用 によりトリグリセリドから脂肪酸, 更に脂肪酸エチル へ変化する ${ }^{7)}$ 。NT12 株では最終的に脂肪酸エチルな どの含量を増加させる効果はそれほど高くなかったが, 第 1 図の脂質組成を見ると, こうした脂肪酸から脂肪 酸エチルへの脂質変化が促進されていると考えられる。

\section{4. 試験醸造したみその機能性}

試験醸造したみそより抽出した脂質について, 抗変 異原性及びガン細胞増殖抑制能を評価した。また, 脂 質に含まれる脂肪酸及び脂肪酸エチルの各成分の活性 を調べるため,それらの市販試薬をあわせて評価した。

抗変異原性は, 菌株を Salmonella typhimurium TA100 (ヒスチジン要求性株), 変異原としてベンゾ ピレンを用いた Ames 試験のプレインキュベーショ ン法により評価した。

その結果を第 2 図, 第 3 図に示した。試薬の評価で は, オレイン酸以外は脂肪酸, 脂肪酸エチルともに不 飽和度が上がるほど抗変異原性が増加し, リノレン酸 エチル以外は脂肪酸エチルより脂肪酸の方が抗変異原 性は高い傾向にあった。今回検討した試薬の中ではリ ノレン酸エチルが最も高い活性を示した。また, みそ 抽出脂質の比較では, 濃度によって多少異なるものの, 全体的に試験区と対照区の抗変異原性はほぼ同程度で あり, 変異株による効果は認められなかった。これは, 試験区のみそは抗変異原性の高い脂肪酸の含量が対照 区より少なく, 抗変異原性の低い脂肪酸エチルが 1.1

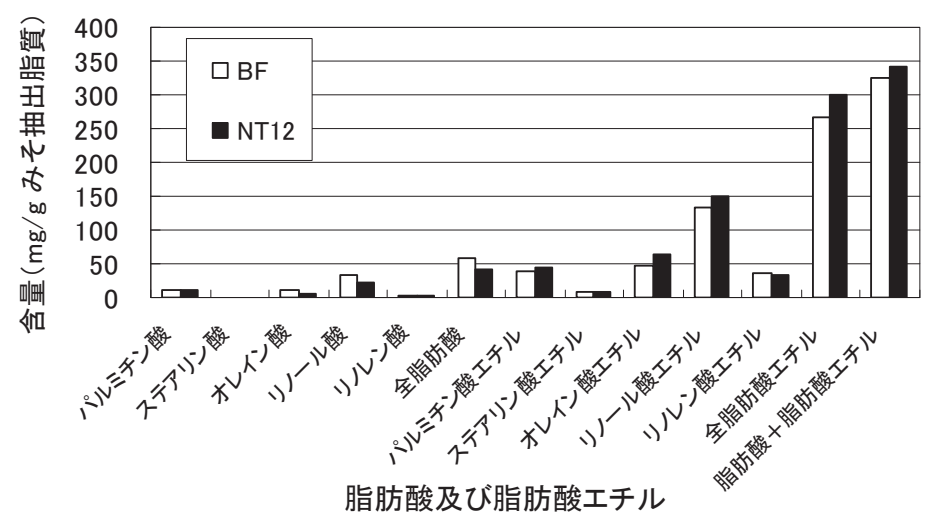

第 1 図 みその脂肪酸及び脂肪酸エチル含量 
倍程度と多かったことから, 結果的に両者の抗変異原 性はそれほど変わらなかったと考えている。

ガン細胞増殖抑制能は上岡らの方法 ${ }^{4)}$ に準じて評価 した。すなわち，ヒト肺扁平上皮ガン細胞 RERF-LC$\mathrm{AI}$ に対し，脂質，L-ジミリストイルポスファチジル コリン (DMPC), Tween80 からなる複合脂質膜を添 加することにより，細胞増殖に与える影響をCell counting kit-8により評価した。試薬の活性は, ウェ ルあたりの添加濃度を $4 \mu \mathrm{g} / 110 \mu \mathrm{l}$ として評価した。

その結果を第 4 図, 第 5 図に示した。試薬の評価で は, 脂肪酸, 脂肪酸エチルともに不飽和度が上がるほ ど増殖抑制能が増加し，オレイン酸エチル以外は脂肪 酸より脂肪酸エチルの方が増殖抑制能は高い傾向にあ った。リノレン酸エチルが最も増殖抑制能が高く、こ れらは上岡ら ${ }^{4)}$ の報告と合致していた。みそ等からの

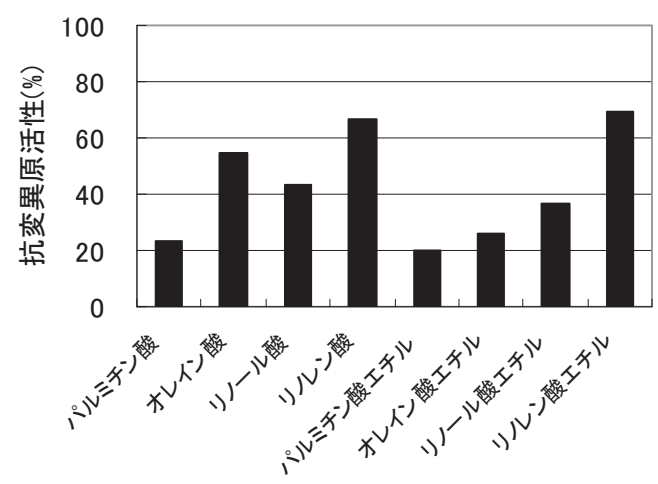

脂肪酸及び脂肪酸エチル

第 2 図脂肪酸, 脂肪酸エチル試薬の抗変異原性 変異処理液での試薬添加濃度 : $0.1 \mathrm{mg} / 720 \mu \mathrm{l}$

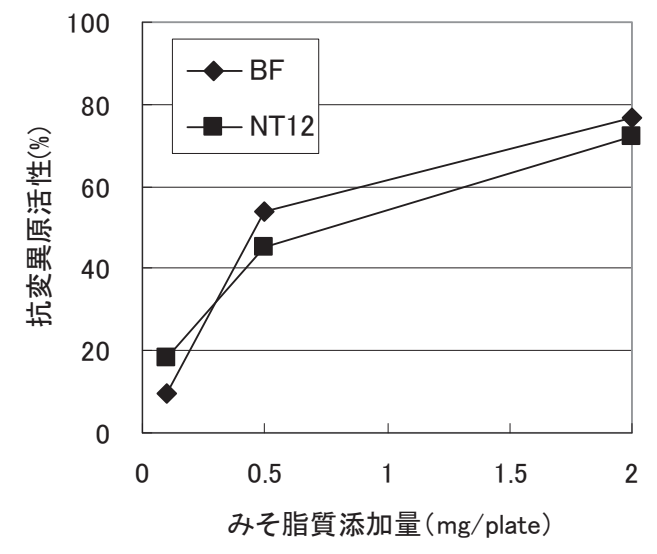

第 3 図 みそ抽出脂質の抗変異原性
抽出脂質の比較では，コントロールである大豆油も添 加量を増やすと増殖抑制能が増加していたものの, み そ由来の脂質は大豆油に比べ高い増殖抑制能を示して いた。これはみその熟成に伴う脂肪酸や脂肪酸エチル の増加に起因すると考えられる。また, 試験区と対照 区の比較では試験区のみそは増殖抑制能がやや向上し ており, 変異株による効果が認められた。これは NT12 株のみそは脂肪酸が少なく, 抑制能が高い脂肪 酸エチルが多いためと考えられる。

\section{5. おわりに}

香味が優れ，機能性を高めたみそを開発することを 目的とし, 変異処理により靝菌リパーゼ高生産株を育 種した。保存株である敖菌Aspergillus oryzae KJ44 を変異処理, スクリーニングし, リパーゼ活性が対照

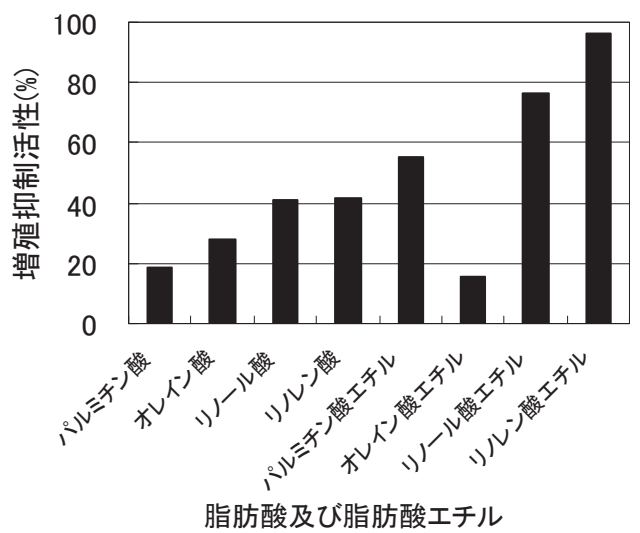

第 4 図 脂肪酸, 脂肪酸エチル試薬のガン細胞増殖抑制 ウェルあたりの試薬添加濃度 : $4 \mu \mathrm{g} / 110 \mu \mathrm{l}$

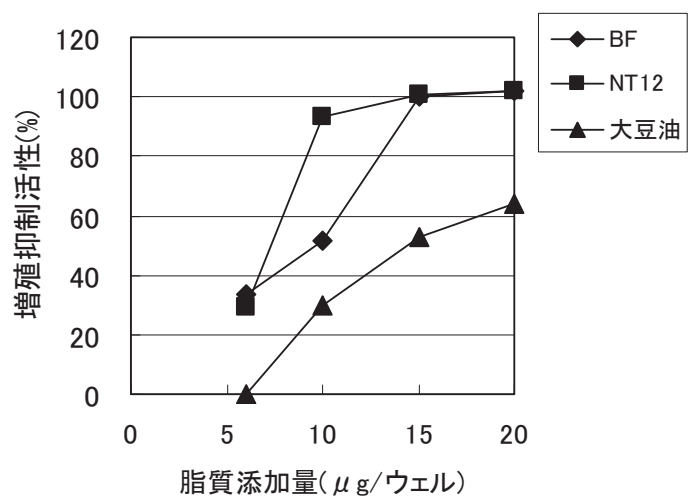

第 5 図 みそ等からの抽出脂質によるガン細胞増殖抑制 
株の約 3 倍生産する NT12 株を選抜した。

次いで, この変異株を用いて小仕込試験を実施し, みその品質や機能性を評価した。NT12 株を種錮とす るみその仕込試験においても, リパーゼ活性は対照株 の約 3 倍であった。みその成分は $\mathrm{x}$ や y が高めで, FN P WSN の值が低めであった。官能評価では，色 のさえが強く, 香りはやや特徵が感じられたものの良 好であり, 総合的にもやや良い評価を得た。NT12 株 のみその全脂肪酸量は対照区よりやや少なかったもの の, 全脂肪酸エチルは 1.1 倍程度に増加した。NT12 株のみそは対照区と比べ抗変異原性はほとんど変わら なかったが，ガン細胞増殖抑制能はやや向上しており 変異株による効果が認められた。これらの機能性の結 果は脂肪酸と脂肪酸エチルの含量の比率を反映した結 果と考えられる。

なお，今回育種した NT12 株については，その後工 場規模での仕込試験を実施するとともに, 県内メーカ 一の実䁔造にも使用された。工場規模の仕込試験にお いても今回紹介した小仕込試験と同様な傾向のみそと なり，実醸造に使用したメーカーからも高評価を得た。 ただし，NT12株について，生育特性が劣ること， プロテアーゼはやや低めであること，活性に比べて脂 肪酸や脂肪酸エチル含量の増加が少なかったことなど は今後の検討課題である。

ところで, 変異処理による麹菌の育種は, 清酒酵母 の育種などの華々しい成果に比べるとまだまだ事例が 少ない感がある。多核であるなど敖菌は酵母に比べる と取り扱いが厄介で成果が出にくい。しかしながら，

醉造・発酵の世界では 1 麹 2 もと 3 造り，あるいは 1 敖 2 櫂 3 火入れなどと言われるように，敖が非常に重 要であることは疑いの余地がない。教菌の酵素生産性 などの諸性質が発酵食品の品質に及ぼす影響を考える と，それに焦点を当てた育種は価值があり，実用化の 可能性も大きいと思われる。錮菌の育種を通じて, 多
様性に富む優れた発酵食品の開発に役立つことができ れば幸いである。

＜長野県工業技術総合センター 食品技術部門＞

\section{参考文献}

1）海老根英雄：味噌の科学と技術，43，1-26 (1995)

2）渡邊敦光：醸協. 105, 714-722（2010）

3）山本和子, 大崎好子, 加藤哲夫, 西島基弘, 宮 崎利夫：味噌の科学と技術，42, 65-70（1994）

4) 岡崎秀, 秋葉美智子, 木村修一：昭和 59 年度 日本農芸化学会大会講演要旨集, 1995, p636

5）上岡龍一, 後藤浩一, 山内彰雄：醸協。 100 , 771-776 (2005)

6）安平仁美：醸協，75，506-515（1980）

7）大西邦男：醸協，78，848-853（1983）

8） 大西邦男：日食工誌，29， 85-92（1982）

9）大西邦男：日食工誌，30， 88-93（1983）

10) J. Toida, K. Kondou, M. Fukuzawa, K. Ohnishi, J. Sekiguchi: Biosci. Biotech. Biochem. 59, 1199-1203 (1995)

11) J. Toida, Y. Arikawa, K. Kondou, M. Fukuzawa, J. Sekiguchi: Biosci. Biotech. Biochem. 62, 759-763 (1998)

12) J. Toida, M. Fukuzawa, G. Kobayashi, K. Ito, J. Sekiguchi: FEMS Microbiol. Lett., 189, 159-164 (2000)

13）渡辺隆幸, 尾張か扔る, 堀一之, 高橋光一： 日本食品科学工学会誌, 51, 698-702（2004）

14） 戸井田仁一, 蟻川幸彦：長野県工業技術総合七 ンター研究報告， 5, F4-F7（2010）

15）全国味増技術会編：基準みそ分析法（1995）

16）日本奨油研究所編：しょうゆ試験法（1985）

17）石田博樹, 秦 洋二, 川戸章嗣, 秋田 修: 特 許公開 $2002-186483$ 